\title{
Study of the gametophytes of Pteris vittata $L$. collected from different localities of Patna to show the effect of pollution on them
}

\author{
PuspanjaliKhare , Dr.MausumiBiswas , Dr.Surendra Kumar Prasad* \\ Dept. of Botany, Magadh Mahila College,Patna University.Patna India
}

\begin{abstract}
Three populations of a common road side fern Pteris vittata L. were collected from three different localities situated in Patna with varying level of pollution. Spores were collected from these ferns and cultured in artificial nutrient medium to grow the gametophytes. Gametophytes show various types of abnormalities including ameristic male prothalli, green antheridia, abnormally elongated prothalli with hyaline and bulbous cells during the course of development, which should be correlated with the various types of pollutants in which these ferns are exposed.

Key Words:Population, artificial nutrient, gametophyte, ferns, pollution, Pterisvittata.
\end{abstract}

\section{Introduction :}

Ferns are characterised by filicaleanmegaphyll andcryptogamic reproduction, are found all over the world ; from high mountains to sea level. As most of the present day ferns are found in rainforest, both tropical and temperate, but some of them have their habitat in shady - fresh water area to semiarid deserts. Few ferns are also very common in urban localities, including industrial and commercial areas of the cities .

All ferns show two distinct phases in their life - cycle : one is sporophytic generation and another is gametophytic generation. Sporophytes are always exposed to different pollutants present in the air as well as in soil. Spores which are produced by sporophytes are also exposed to the pollution. In the city of Patna , increasing number of automobiles, industries create a threat on the biotic components of the ecosystem. As ferns are one of the major components of the ecosystem and occur a key position in the ecosystem, so the effect of pollution is quite easily visible upon them. Spores Which are produced in the sporophytes that are exposed in the pollutants, show different types of abnormalities after germination. Spores of ferns germinated to the gametophytes and after germination shows different types of abnormalities. Gametophytes after completion of gametophytic phase, produces embryoes. From these embryos, one potent grows into juvenile sporophyte.

PterisVittila L.is the most common road side fern which is more or less exposed to the pollutant throughout their life cycle. Spores which are produced in these sporophytes, germinate into gametophytes. Pollutants that causes abnormalities in the spores show them in the form of abnormal gametophytes that are grown in culture medium and observations are taken to correlate the abnormalities with the localities. On the basis of types of abnormalities present and by calculating their percentage, conclusion can be drawn that which area is the most polluted one from where the specimens were collected.

\section{Material and Method}

Spores of the common road-side fern Pterisvittala L. are collected from three different localities of Patna. These localities are:

(1) Garden area; from the ground of the house, located in khajpura area, which is more or less unpolluted area

(2) Near the sewage; where plants are exposed in pollutant of industries near patliputra industrial area.

(3) From the crevices of the old house which is exposed to the automobile exhaust and different garbage from the 'saguna more' area.

Spores of khajpura area is considered as control because they are growing more or less in unpolluted area. The spores collected from Patliputra industrial area is considered as $\underline{\text { Sample } 2 \text {; where }}$ as_spores collected from saguna more area is considered as Sample $\mathbf{3}$.

All the spores are sterilized by $0.5 \%$ Ca hypochlorite solution for 5 minutes. There spores are inoculated in modified Moore's medium supplimented with Nitch's trace element. These cultures are maintained at $22 \pm 0^{\circ} \mathrm{c}$ with $16 \mathrm{hrs}$.of illumination in $24 \mathrm{hrs}$. cycle under constant source of 1000 lux . 


\section{Observation:}

Sample 1 : Spores are pale brown, tetrahedral with trilete aperture, the equatorial rim distinct, sporodermbacculate. Spores measure $21.26 \pm 1.63$ ex $\mu \mathrm{m}$ to $28.11 \pm 1 \cdot 16 \mu \mathrm{m}$ in diameter .

Each sporangium contains 64 spores, of which $80.8 \%$ germinate \& $19.2 \%$ are abortive in nature . Abortive spores are pale brown to hyaline, comparatively small, ill developed \& they do not germinate even after prolong culture .

After inoculation spore nucleus becomes larger due to imbibitions and it enters into the divisional cycle. After $74 \mathrm{hrs}$ of inoculation, the sporoplasm divides into two unequal halves by a mitotic division. From the smaller half the rhizoidal initial ( $\mathrm{R}_{1}$ ) comes out first ( fig 1.1 ) from the larger half of the sporoplasm the first chlorocycyte $\left(c_{1}\right)$ emerges almost simultaneously after the emergence of the primary rhizoidal cell . the primary rhizoid $\left(R_{1}\right)$ is hyaline, flexuous and become considerably long when the germ filament attends 4 called stage .

After successive mitotic divisions two dimensional growth initiated in the germ filament.The sequence of the mitotic division are listed in the following table

Table 1.1 : sequence of mitotic divisions \& cell cycle Periodicity in 4 celled germ filaments and the commencement of $2-D$ growth

\begin{tabular}{|c|c|c|c|c|}
\hline Sr. No. & $\begin{array}{l}\text { Number of mitotic } \\
\text { divisions }\end{array}$ & $\begin{array}{l}\text { Time period for each } \\
\text { div. Cycle (in hours } \\
\text { ) }\end{array}$ & Plane of division & $\begin{array}{l}\text { Components of germ } \\
\text { - filament }\end{array}$ \\
\hline 1 & $\mathrm{M}_{\mathrm{I}}$ & 74 & Transverse & $\mathrm{R}_{1} \mathrm{C}_{1}$ \\
\hline 2 & $\mathrm{M}_{\mathrm{II}}$ & 46 & Oblique & $\mathrm{R}_{1} \mathrm{C}_{1} \mathrm{C}_{2}$ \\
\hline 3 & $\overline{\mathrm{M}_{\text {III }}}$ & $2^{1} / 2$ & -Do - & $\mathrm{R}_{1} \mathrm{R}_{2} \mathrm{C}_{1} \mathrm{C}_{2}$ \\
\hline 4 & $\mathrm{M}_{\mathrm{IV}}$ & 16 & Transverse & $\mathrm{R}_{1} \mathrm{R}_{2} \mathrm{C}_{1} \mathrm{C}_{2} \mathrm{C}_{3}$ \\
\hline 5 & $\overline{M_{V}}$ & 14 & -do- & $\mathrm{R}_{1} \mathrm{R}_{2} \mathrm{C}_{1} \mathrm{C}_{2} \mathrm{C}_{3} \mathrm{C}_{4}$ \\
\hline 6 & $\mathrm{M}_{\mathrm{VI}}$ & 19 & Vertical & $\begin{array}{l}\mathrm{R}_{1} \mathrm{R}_{2} \mathrm{C}_{1} \mathrm{C}_{2} \mathrm{C}_{3} \mathrm{C}_{4^{-}} \\
2 \mathrm{D}\end{array}$ \\
\hline
\end{tabular}

During the development stages, cells of the germ filaments expand in their length and width. The fully mature chlorocytes are stout, more or less isodiametric to little elongate, deep - green and densely cytoplasmic (fig.1.2) The lengths of the chlorocytes vary from $57.23 \mu \mathrm{m}$ to $59.59 \mu \mathrm{m}$ and width vary from 30.2 to 37.17 $\mu \mathrm{m}$.

After the initiation of 2 -D growth, distal cells undergo few quick divisions forming a small, spatulate 8-10 celled cell plate (fig. 1.3 ). Branching tendency in quite frequent ( 1.4 ). Apical cells develops after $7^{\text {th }}$ day of germination and it is derived by an oblique division at the distal lateral side of the cell plate ( fig.1.5 ). It is triangular, broad, densely cytoplasmic cell with a prominent nucleus, which form a band of maristematic cells, which later shifted at the middle. Mid - cushion appears on the $35^{\text {th }}$ day after germination, which is thick and extended from apex to basal part (fig.1.6)

The developmental pathways of gametophytes show three different types of prothalli in the culture. Male prothalli appear first in the 23 days old culture, which may be ameristic or meristic. The ameristic male prothalli are either branched or thalloid type, which are short lived, very few in number and bear only 3 - 4 superficial antheridia ( fig 1.7 ). The meristic prothalli later changed to bisexuals by developing archaegonia in 44 days old gametophytes. In these bisexual prothalli antheridia develop at the basal part and archaegonia below the apical notch . ( figs. 1.8) Female prothalli appear late in culture. They are very similar with bisexual ones but bear only archaegonia, ( fig 1.9 ). The size range of three types gametophytes are recorded in the following table

Table 1.2 : measurement of three types of gametophytes in the basal medium .

\begin{tabular}{|l|l|l|l|}
\hline Sr. no. & Types of prolthalli & Length range $(\mathrm{mm})$ & Width - rang $(\mathrm{mm})$ \\
\hline 1. & Ameristic male & $0.76-0.99$ & $0.46-0.51$ \\
\hline 2. & Meristic bisexual & $2.02-2.53$ & $3.5-3.75$ \\
\hline 3. & Meristic female & $2.05-2.28$ & $3.05-3.28$ \\
\hline
\end{tabular}

Antheridia are sessile, globose and superficial, consist of a single opercular cell, single basal cell and single ring cell ( fig 1.10 ). Size of antheridia vary from $52.30 \mu \mathrm{m}$ to $54.04 \mu \mathrm{m}$ in diameter . Antheridia of ameristic males are very much similar to the antheridia of meristic prothalli, but they are short lived .

Archaegonia first appear below the apical notch and are arranged in several rows, but later shifted below on the mid cushion in older prothalli. The archaegonia are directed either laterally or downwardly .Archaegonia are initially very few in number being only $4-8 /$ prothallus but later increase with the age of 
prothalli and become 15 - 18 on each prothallus. These are slightly sunken, curved and elliptical to oval shape ; each one consisting of a single prominent egg, single venter canal cell and single binucleate neck canal cell, is surrounded by $4-5$ neck cells in each row ( fig 1.11 ). They open at their neck region to facilitate the fertilization.

In composite culture zygote is formed after fertilization which undergoes first obliquely vertical division forming a 2 - celled structure which is followed by another transverse division producing a quadrant .Zygotes are $6-8$ on each prothallus and are deeply seated in gametophytic tissue . Multicellular embryos develop from the zygotes by several other divisions and are surrounded by $2-3$ layers of cells. Among these embryos only single potent embryo is developed into juvenile sporophyte (1.12). After 93 days of germination about $70 \%$ bisexual prothalli and $20 \%$ of female prothalli developed juvenile sporophytes in the composite culture .

\section{Sample 2:}

Spores are pale brown, tetrahedral with trilete aperture, with the distinct equatorial rim. Sporoderm is bacculate, similar to that of sample 1. Spores measure $19.26 \pm 1.52 \mu \mathrm{m}$ to $27.01 \pm 1.12 \mu \mathrm{m}$ in diameter .

Each sporangium contains 64 spores of which $60.4 \%$ germinate and $39.6 \%$ are abortive in nature. Abortive spores are pale brown to hyaline, ill - developed and remain non germinated even after a long time of cultur. After 82 hours of inoculation, the sporoplasm divides into unequal halves by a mitotic division. The first rhizoidal initial $\left(R_{1}\right)$ comes out from the smallerhalf of the sporoplasm (fig. 2.1 ).After several mitotic division the germ filament becomes 4 celled and $2 \mathrm{D}$ growth is initiated.Sequence of mitotic divisions are enlisted in the following table.

Table 2.1 : Sequence of mitotic divisions \& cell cycle periodicity in 4 celled germ filament and the commencement of $2-D$ growth .

\begin{tabular}{|l|l|l|l|l|}
\hline Sr. No. & $\begin{array}{l}\text { Number of mitotic } \\
\text { divisions. }\end{array}$ & $\begin{array}{l}\text { Time period for each div. } \\
\text { Cycle (in hours ) }\end{array}$ & Plane of division & $\begin{array}{l}\text { Components of germ } \\
\text { filament }\end{array}$ \\
\hline 1. & $\mathrm{M}_{\mathrm{I}}$ & 82 & Transverse & $\mathrm{R}_{1} \mathrm{C}_{1}$ \\
\hline 2. & $\mathrm{M}_{\mathrm{II}}$ & 58 & -do- & $\mathrm{R}_{1} \mathrm{C}_{1} \mathrm{C}_{2}$ \\
\hline 3. & $\mathrm{M}_{\mathrm{III}}$ & 4 & Oblique & $\mathrm{R}_{1} \mathrm{R}_{2} \mathrm{C}_{1} \mathrm{C}_{2}$ \\
\hline 4. & $\mathrm{M}_{\mathrm{IV}}$ & 20 & Transverse & $\mathrm{R}_{1} \mathrm{R}_{2} \mathrm{C}_{1} \mathrm{C}_{2} \mathrm{C}_{3}$ \\
\hline 5. & $\mathrm{M}_{\mathrm{V}}$ & 22 & -do- & $\mathrm{R}_{1} \mathrm{R}_{2} \mathrm{C}_{1} \mathrm{C}_{2} \mathrm{C}_{3} \mathrm{C}_{4}$ \\
\hline 6. & $\mathrm{M}_{\mathrm{VI}}$ & 26 & Vertical & $\mathrm{R}_{1} \mathrm{R}_{2} \mathrm{C}_{1} \mathrm{C}_{2} \mathrm{C}_{3} \mathrm{C}_{4}-2 \mathrm{D}$ \\
\hline
\end{tabular}

The fully mature chlorocytes are stout, more or less isodiametric to little elongate, deep green and densly cytoplasmic . The lengths of the chlorocytes vary from $53.26 \mu \mathrm{m}$ to $56.85 \mu \mathrm{m} \&$ width varies from $28.28 \mu \mathrm{m}$ to $30.64 \mu \mathrm{m}$. With the onset vertical division, two dimensional growth of the gametophyte begins on 5 days and 10 hours old germ filament (fig.2.2).Some abnormal long branched filamentous prothalli are common in the composite culture which later changed into ameristic male prothalli ( fig 2.3 ). In other types, by repeatative divisions spatulate cell plates are formed. Apical cell develops on $9^{\text {th }}$ day after germination and it is derived by an oblique division at the distal lateral side of the cell plate which form the meristematic cells by several divisions.

Mid cushion appears on the $37^{\text {th }}$ day after germination in young prothalli , it is very narrow and slender but later become think and extended from apex to the basal part.

The developmental pathways of gametophytes show three different types of prothalli in the composite culture . The ameristic male prothalli with abnormal branching and with bulbous basal cells appear quite earlier in the culture which bear normal and as well as green antheridia ( fig 2.4 ). These prothalli are short lived and started degenerating in 30 days old culture . The meristic male prothalli later changed to the bisexuals by developing archaegonia in 47 day old gametophytes .Archaegonia appear just below the apical notch , where as antheridia are restricted at the wings \& the basal part of the prothalli ( fig 2.5 ). Female prothalli are much less in number and appear late in the culture. They are very similar to the bisexuals but bear only archaegonia. The size range of three types of gametophytes are recorded in the following table ( table 2.3 ).

Table 2.2 : Measurement of three types of gametophytes in the basal medium .

\begin{tabular}{|l|l|l|l|}
\hline Sr. no. & Types of prothalli & Length range $(\mathrm{mm})$ & Width range $(\mathrm{mm})$ \\
\hline 1. & Ameristic male ( cell - plate ) & $0.67-0.72$ & $0.38-0.43$ \\
\hline 2. & Meristic bisexual & $1.98-2.43$ & $2.46-3.16$ \\
\hline 3. & Meristic female & $2.05-2.5$ & $2.8-3.1$ \\
\hline
\end{tabular}

Antheridia are sessile, globose and superficial and their structure is very much similar to the antheridia of sample 1. Movement of antherozoids is sluggish . 
Archaegonia first appear below the apical notch and they are also very similar to that of the sample 1. In composite culture, zygote is formed after fertilization. They are deep seated within the gametophytictissue . By several divisions, multicellular embryos develop from the zygotes, which are surrounded by $2-3$ layers of cells and deeply seated in gametophytic tissue .In composite culture sporophyte develop in 105 day old gametophyte. Most of the archaegonia of female prothalli become necrotic. About $40 \%$ bisexual prothalli bear sporophyte, where as only $5 \%$ female prothalli bear sporophyte .

\section{Sample 3 :}

Spores are pale, little brownish, tetrahedral with trilete aperture, with a distinct equatorial rim . Sporoderm is bacculate. Spores measure $18.06 \pm 1.43 \mu \mathrm{m}$ to $25.12 \pm 1.12 \mu \mathrm{m}$ in diameter .

Within a mature sporangium , 64 spores are present of which only $50.6 \%$ germinate and $49.4 \%$ are abortive in nature . Abortive spores are ill - developed, pale brown to hyaline, small \& remain ungerminated for a long time in the culture medium .

After 96 hours of inoculation, the sporoplasm divides into two unequal halves by a mitotic division. From the smaller half the rhizoidal initial $\left(\mathrm{R}_{1}\right)$ comes out first and from the larger half of the sporoplasum the first chlorocyte $\left(\mathrm{C}_{1}\right)$ emerges almost simultaneously (Fig.3.1).

After a series of mitotic divisions 2D growth is initiated in 4 celled long germ filament and the sequences are shown in the following table.

Table 3.1 : sequence of mitotic divisions and cell cycle periodicity in 4 celled germ filament and commencement of 2- D growth .

\begin{tabular}{|l|l|l|l|l|}
\hline Sr. No. & $\begin{array}{l}\text { Number of mitotic } \\
\text { division }\end{array}$ & $\begin{array}{l}\text { Time period each } \\
\text { divisional cycle (in } \\
\text { hours ) }\end{array}$ & Plane of division & $\begin{array}{l}\text { Components of the germ } \\
- \text { filament }\end{array}$ \\
\hline 1. & $\mathrm{M}_{\mathrm{I}}$ & 96 & Transverse & $\mathrm{R}_{\mathrm{I}} \mathrm{C}_{\mathrm{I}}$ \\
\hline 2. & $\mathrm{M}_{\mathrm{II}}$ & 84 & Transverse & $\mathrm{R}_{\mathrm{I}} \mathrm{C}_{\mathrm{I}} \mathrm{C}_{2}$ \\
\hline 3. & $\mathrm{M}_{\mathrm{III}}$ & 10 & Oblique & $\mathrm{R}_{1} \mathrm{R}_{2} \mathrm{C}_{1} \mathrm{C}_{2}$ \\
\hline 4. & $\mathrm{M}_{\mathrm{IV}}$ & 26 & Transverse & $\mathrm{R}_{1} \mathrm{R}_{2} \mathrm{C}_{1} \mathrm{C}_{2} \mathrm{C}_{3}$ \\
\hline 5. & $\mathrm{M}_{\mathrm{V}}$ & 26 & Transverse & $\mathrm{R}_{1} \mathrm{R}_{2} \mathrm{C}_{1} \mathrm{C}_{2} \mathrm{C}_{3} \mathrm{C}_{4}$ \\
\hline 6. & $\mathrm{M}_{\mathrm{VI}}$ & 28 & Vertical & $\mathrm{R}_{1} \mathrm{R}_{2} \mathrm{C}_{1} \mathrm{C}_{2} \mathrm{C}_{3} \mathrm{C}_{4}-2 \mathrm{D}$ \\
\hline
\end{tabular}

The fully mature chlorocytes are deep green, isodiametric to elliptical, and densely cytoplasmic . The length of the chlorocytes vary from $48.08 \mu \mathrm{m}$ to $52.16 \mu \mathrm{m}$ and width vary from $25.06 \mu \mathrm{m}$ to $32.15 \mu \mathrm{m}$

In the composite culture, after the initiation of $2-\mathrm{D}$ growth in some filaments distal cells undergo few quick divisions, thus forming a small spatulate $8-10$ celled cell plate ( fig 3.2 ). Branching tendency and abnormal elongation of cells is quite is frequent, forming abnormally elongated prothalli .These abnormal prothalli are short lived and bear green non functional antheridia showing the effect of pollution on the spores

In the spatulate cell plates, apical cell develop on $11^{\text {th }}$ day after germination, and forms lateral meristem . Mid cushion appear on the $45^{\text {th }}$ day after germination.

The developmental pathways of the gametophytes in the composit culture shows three types of prothalli. The short lived ameristic filamentous abnormal prothalli survived in $70-75$ days old culture and occasionally bear only $2-3$ functional anitheridia. Meristic prothalli first bear antheridia which appears in 56 day old gametophytes. Antheridia are $4-8$ in the mature gametophytes which are distributed at the wings

Female prothalli appear quite late in the culture and are very much similar to the bisexual one, but bear only archaegonia on the mid cushion below the apical notch. The size range of three types of gametophytes are recorded in the following table ( table 3.3 ).

Table 3.2 : Measurement of three type of gametophytes :

\begin{tabular}{|l|l|l|l|}
\hline Sr. No. & Types of prothalli & Length - range $(\mathrm{mm})$ & Width - range $(\mathrm{mm})$ \\
\hline 1. & Ameristic male & $0.50-0.70$ & $0.32-0.40$ \\
\hline 2. & Meristic bisexual & $1.75-2.00$ & $2.52-2.78$ \\
\hline 3. & Meristic female & $1.85-2.05$ & $2.60-3.00$ \\
\hline
\end{tabular}

Viable antheridia and archaegonia are very much similar to that of sample 1.

In composite culture zygote is formed after fertilization and from which multicellular embryos are formed which are deeply situated in gametophytic tissue Among these embroes only one polent embryo is developed into juvenite sporophyte ( fig 3.3). Number of sporophytes in this sample is quite less than sample 1 and sample 2 .Only $25 \%$ of the bisexuals prothalli\& $3 \%$ of female prothalli bear sporophytes which emerges on $120^{\text {th }}$ days old culture . 


\section{Discussion :}

Developmental, structural and diagnostic features of prothalli of Pteris vittata $L$. in different localities exposed to different level of pollution :

Majority of the spores collected from the garden area of khajpura, which is more or less unpolluted area and exposed to less pollutants ; are healthy , functional and remain intermixed with some non-functional, abortive or ill developed spores which never germinate after a prolong culture. The spores collected near sewage in patliputra area are exposed to the industrial effluents are less healthy . Percentages of abortive spores are more than the sample $1 \&$ do not germinate even after prolong culture. Spores collected from crevices of the wall of the old house, exposed to automobile exhaust at 'saguna more ' area more abortive. Measurement of the spores changes in different localities. In sample 1 spores are healthy, where as their size decreases in sample $2 \&$ sample 3 . The size range of spores in three samples are listed in table 4.1 .

Table 4.1 : Comparison of size of the spores in three samples collected .

\begin{tabular}{|l|l|}
\hline Sample 1. & $21.26 \pm 1.63 \mathrm{em}$ to $28.11 \pm 1.16 \mathrm{em}$ \\
\hline Sample2. & $19.26 \pm 1.52 \mathrm{em}$ to $27.01 \pm 1.12 \mathrm{em}$ \\
\hline Sample3. & $18.06 \pm 1.43 \mathrm{em}$ to $25.12 \pm 1.12 \mathrm{em}$ \\
\hline
\end{tabular}

Germination percentage is higher in sample 1 , and gradually decreases in sample 2 and in sample 3 . this is represented in table 4.2 .

Table 4.2 : Comparison of fertile and abortive spore percentages of three samples .

\begin{tabular}{|l|l|l|}
\hline Sample & Percentage of fertile spore & Percentage of abortive spore \\
\hline Sample 1 & $80.8 \%$ & $19.2 \%$ \\
\hline Sample 2 & $60.4 \%$ & $39.6 \%$ \\
\hline Sample 3 & $50.6 \%$ & $49.4 \%$ \\
\hline
\end{tabular}

Germination time is also dissimilar in all the three samples . Germination time is much less is samples 1 , where as it is gradually in creases in sample $2 \&$ sample 3 . Comparison of germination time is tabulated in table 4.3 .

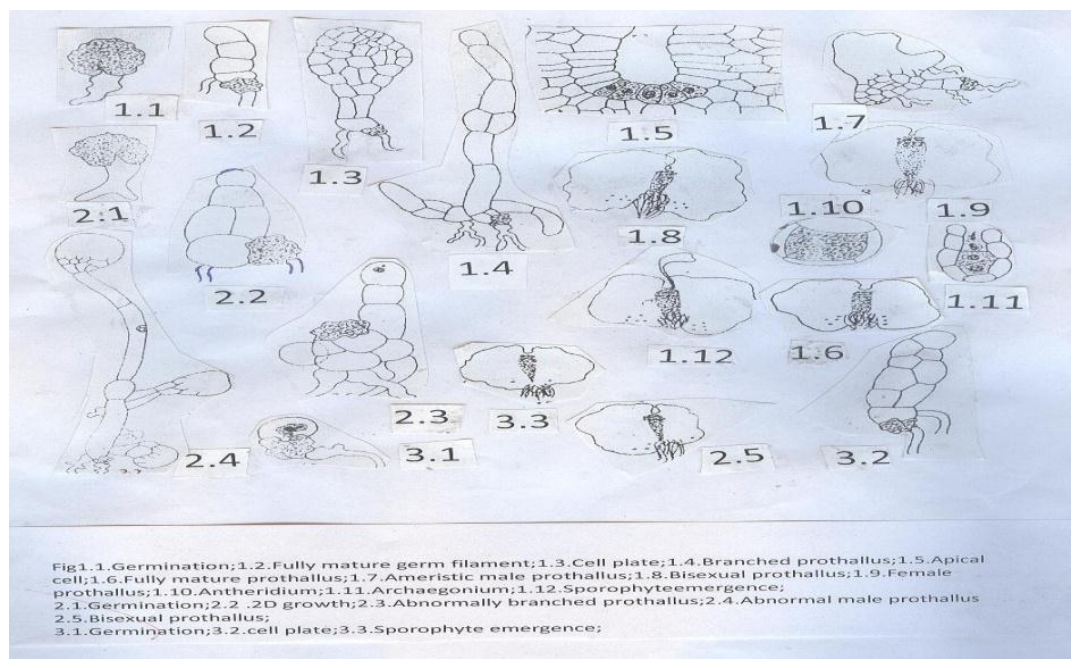

Table 4.3 : Comparison of germination time of the three samples .

\begin{tabular}{|l|l|}
\hline Sample & Germination time after inoculation ( in hr. ) \\
\hline Sample 1 & 74 hours \\
\hline Sample 2 & 82 hours \\
\hline Sample 3 & 96 hours \\
\hline
\end{tabular}

Apical cell develop in the sample 1 after $7^{\text {th }}$ day of germination, where as the appearance time become late in sample 2 and 3 , which is on $9^{\text {th }}$ day $\&$ on $11^{\text {th }}$ day respectively after germination. Type of the prothalli shows abnormalities in sample 2 band 3 . Cell plates of sample one is spatulate with distinct apical notch, where few ameristicprothalli appeared in the culture . In sample 2 , abnormal branching tendency is more, where abnormal elongated cells are frequent in the culture with hyaline bulbous cells. These types of prothalli are common in the culture that contains heavy metal salts of $\mathrm{Hg}, \mathrm{Pb}$ and $\mathrm{Cd}$.

Composite culture of sample 3 also contains abnormal filamentous ameristic prothalli with bulbous \& abnormal elongated cells that confirms that spores are exposed to the pollutants that contain the salts of heavy 
metals . Presence of abnormal branch ameristicprothalli confirms the presence of heavy metals in the soil from where these sample are collected .

In the three samples, in the composite culture three types of prothalli are common, i. e . Ameristicmale , meristic bisexual \& meristic female. In sample 1 , the size of the prothalli are bigger than both sample 2 and sample 3 . The size range of all the samples are listed in following table ( table 4.5 ).

Table 4.4 : comparison of the size range of the prothalli studied .

\begin{tabular}{|l|l|l|l|l|l|l|}
\hline Sample & \multicolumn{2}{|l|}{ Ameristic male $(\mathrm{mm})$} & \multicolumn{2}{l|}{ Meristic bisexual } & \multicolumn{2}{l|}{ Meristic female } \\
\hline & $\begin{array}{l}\text { Length } \\
(\mathrm{mm})\end{array}$ & Width $(\mathrm{mm})$ & $\begin{array}{l}\text { Length } \\
(\mathrm{m})\end{array}$ & Width $(\mathrm{mm})$ & $\begin{array}{l}\text { Length } \\
(\mathrm{mm})\end{array}$ & Width $(\mathrm{mm})$ \\
\hline Sample 1 & $0.76-$ & $0.46-0.51$ & $2.02-2.53$ & $3.5-3.75$ & $2.05-2.28$ & $3.05-3.28$ \\
& 0.99 & & & & & \\
\hline Sample 2 & $0.67-$ & $0.38-0.43$ & $1.98-2.43$ & $2.46-3.16$ & $2.05-2.5$ & $2.8-3.1$ \\
\hline Sample 3 & 0.72 & & & & & \\
\hline
\end{tabular}

From the above table it is clear that sample 1 shows more or less normal mode of development, where as the sample $2 \&$ sample 3 show the degenerating mode because sample $2 \& 3$ are growing in polluted area exposed to different pollutants. Growth of the gametophytes show degenerating mode when exposed to various heavy metal salts which are present in the soil.

Antheridia appear both in ameristic and meristic prothalli in all the three samples. In sample 1 , antheridia of both ameristic\& meristic prothalli are viable \& functional with heavy antherozoidal mass . In sample 2 and 3 antheridia of abnormally branched prothalli are green \&nonviable; become necrotic after a short time ; confirming the presence of heavy metals (Gupta,M. And Devi, S.1992).Antheridia of thalloidameristic male \& meristic bisexuals are few in number than that of the prothalli of sample 1 Antherozoidal mass is scanty both in sample 2 and sample 3 .

Size range of the antheridia of sample $2 \& 3$ shows decreasing trend in size compared to that of sample 1 .

Archaegonia appear in all the samples. Their number shows decreasing trend in number, number archeagonia are more in sample 1 that of the sample $2 \& 3$. Structure of the archaegonia are same in all the specimens, but number of viable archaegonia are less \& number of necrotic archaegonia are more in sample 2 and sample 3 , compare to that of the sample 1 . Table 4.6 shows the size range of antheridia of three sample , their arrival time and arrival time of archaegonia .

Table 4.5 : Size range ; arrival time of antheridia , and arrival time of archaegonia of the three samples .

\begin{tabular}{|l|l|l|l|}
\hline Sample & Arrival time of antheridia & Size & Arrival time of archaegonia \\
\hline Sample 1 & $23^{\text {rd }}$ day after germination & $52.30 \mathrm{em}-54.04 \mathrm{em}$ & $56^{\text {th }}$ day after germination \\
\hline Sample 2 & $26^{\text {th }}$ day after germination & $46.06-51.30 \mathrm{em}$ & $60^{\text {th }}$ day after germination \\
\hline Sample 3 & 30 trh day after germination & $42.30-46.15 \mathrm{em}$ & $67^{\text {th }}$ day after germination \\
\hline
\end{tabular}

Fertilization is normal in case of sample 1 , where in 93 day old culture $70 \%$ bisexual prothalli and $20 \%$ female prothalli bear sporophytes. In case of sample 2 , sporophyte emerges on 105 days old culture where $40 \%$ bisexual prothalli\& only $5 \%$ female prothalli bear sporophytes . In case of sample 3 , emergence of sporophyte takes place on $120^{\text {th }}$ days old culture where only $25 \%$ of bisexual prothalli and $3 \%$ of female prothalli bear sporophytes. The percentage of sporophyte emergence\& their arrival time is listed in table 4.7

Table 4.6 : Percentage of sporophyte emergence \& their arrival time in the three samples.

\begin{tabular}{|l|l|l|l|}
\hline Sample & Percentage of sporophyte emergence & Time of sporophyte emergence \\
\hline & Bisexual prothalli & Female prothalli & \\
\hline Sample 1 & $70 \%$ & $20 \%$ & 93 days old culture \\
\hline Sample 2 & $40 \%$ & $5 \%$ & 105 days old culture \\
\hline Sample 3 & $25 \%$ & $3 \%$ & $120^{\text {th }}$ days old culture \\
\hline
\end{tabular}

Reducing trend of sporophyte emergence in sample 2 and sample 3 confirms that these two samples are growing in more polluted area than that of the sample 1 . All the observations show that the sporophytes of sample 2 sample 3 are exposed to the different pollutants present in the sewage $\&$ also in the atmosphere . These pollutants contain many particulate matter \& the salts of heavy metals like $\mathrm{Pb}^{++}, \mathrm{Cd}^{++}$or $\mathrm{Hg}^{++}$which have retarding effect on the developmental pathways of the gametophyte (Ho, B. And Tai, K.U.1985)

Conclusion

According to these observations we can conclude that the sample 1 of Pterisvittata $L$ collected from the garden of khajpura shows the normal developmental pathways; but the sample 2 and sample 3 of Pteris vittata $L$.that are collected near sewage of patliputra industrial area and from crevices of the wall of 
old house are grown in polluted area and the adverse effect of the pollution will be seen on the developmental pathways of the gametophytes

\section{Discussion :}

Developmental, structural and diagnostic features of prothalli of Pterisvittata $L$. in different localities exposed to different level of pollution :

Majority of the spores collected from the garden area of khajpura, which is more or less unpolluted area and exposed to less pollutants ; are healthy , functional and remain intermixed with some non-functional, abortive or ill developed spores which never germinate after a prolong culture . The spores collected near sewage in patliputra area are exposed to the industrial effluents are less healthy . Percentages of abortive spores are more than the sample $1 \&$ do not germinate even after prolong culture. Spores collected from crevices of the wall of the old house, exposed to automobile exhaust at 'saguna more ' area more abortive. Measurement of the spores changes in different localities. In sample 1 spores are healthy, where as their size decreases in sample $2 \&$ sample 3 . The size range of spores in three samples are listed in table 4.1 .

Table 4.1:Comparison of size of the spores in three samples collected .

\begin{tabular}{|l|l|}
\hline Sample 1. & $21.26 \pm 1.63 \mathrm{em}$ to $28.11 \pm 1.16 \mathrm{em}$ \\
\hline Sample2. & $19.26 \pm 1.52 \mathrm{em}$ to $27.01 \pm 1.12 \mathrm{em}$ \\
\hline Sample3. & $18.06 \pm 1.43 \mathrm{em}$ to $25.12 \pm 1.12 \mathrm{em}$ \\
\hline
\end{tabular}

Germination percentage is higher in sample 1 , and gradually decreases in sample 2 and in sample 3 . this is represented in table 4.2 .

Table 4.2 : Comparison of fertile and abortive spore percentages of three samples .

\begin{tabular}{|l|l|l|}
\hline Sample & Percentage of fertile spore & Percentage of abortive spore \\
\hline Sample 1 & $80.8 \%$ & $19.2 \%$ \\
\hline Sample 2 & $60.4 \%$ & $39.6 \%$ \\
\hline Sample 3 & $50.6 \%$ & $49.4 \%$ \\
\hline
\end{tabular}

Germination time is also dissimilar in all the three samples . Germination time is much less is samples 1 , where as it is gradually in creases in sample $2 \&$ sample 3 . Comparison of germination time is tabulated in table 4.3.

Table 4.3 : Comparison of germination time of the three samples .

\begin{tabular}{|l|l|}
\hline Sample & Germination time after inoculation ( in hr. ) \\
\hline Sample 1 & 74 hours \\
\hline Sample 2 & 82 hours \\
\hline Sample 3 & 96 hours \\
\hline
\end{tabular}

Apical cell develop in the sample 1 after $7^{\text {th }}$ day of germination, where as the appearance time become late in sample 2 and 3 , which is on $9^{\text {th }}$ day $\&$ on $11^{\text {th }}$ day respectively after germination.(Dutta K. P. And Sen ,T. 1992) Type of the prothalli shows abnormalities in sample 2 band 3 . Cell plates of sample one is spatulate with distinct apical notch, where few ameristicprothalli appeared in the culture (Das,S.k. Sharma, A, and Talukdar, G. 1982 \& Mukherjee, A.Sharma ,A. And Talukdar, G.1984) In sample 2, abnormal branching tendency is more, where abnormal elongated cells are frequent in the culture with hyaline bulbous cells . These types of prothalli are common in the culture that contains heavy metal salts of $\mathrm{Hg}, \mathrm{Pb}$ and $\mathrm{Cd}$. (Gupta, M. and Devi,S.1992)

Composite culture of sample 3 also contains abnormal filamentous ameristicprothalli with bulbous \& abnormal elongated cells that confirms that spores are exposed to the pollutants that contain the salts of heavy metals . Presence of abnormal branch ameristicprothalli confirms the presence of heavy metals in the soil from where these sample are collected (Francis , P.C. and Petersen ,R.L.1986)

In the three samples, in the composite culture three types of prothalli are common, i. e . Ameristic male, meristic bisexual \& meristic female .In sample 1 , the size of the prothalli are bigger than both sample 2 and sample 3.( Dyer, A. F. 1979) The size range of all the samples are listed in following table ( table 4.5 ).

Table 4.4 :comparison of the size range of the prothalli studied .

\begin{tabular}{|l|l|l|l|l|l|l|}
\hline Sample & \multicolumn{2}{|l|}{ Ameristic male $(\mathrm{mm})$} & \multicolumn{2}{l|}{ Meristic bisexual } & \multicolumn{2}{l|}{ Meristic female } \\
\hline & $\begin{array}{l}\text { Length } \\
(\mathrm{mm})\end{array}$ & Width $(\mathrm{mm})$ & Length $(\mathrm{m})$ & Width $(\mathrm{mm})$ & Length (mm) & Width $(\mathrm{mm})$ \\
\hline Sample 1 & $0.76-0.99$ & $0.46-0.51$ & $2.02-2.53$ & $3.5-3.75$ & $2.05-2.28$ & $3.05-3.28$ \\
\hline Sample 2 & $0.67-0.72$ & $0.38-0.43$ & $1.98-2.43$ & $2.46-3.16$ & $2.05-2.5$ & $2.8-3.1$ \\
\hline Sample 3 & $0.50-0.70$ & $0.32-0.40$ & $1.75-2.00$ & $2.52-2.78$ & $1.85-2.05$ & $2.26-3.00$ \\
\hline
\end{tabular}


From the above table it is clear that sample 1 shows more or less normal mode of development, where as the sample $2 \&$ sample 3 show the degenerating mode because sample $2 \& 3$ are growing in polluted area exposed to different pollutants. Growth of the gametophytes show degenerating mode when exposed to various heavy metal salts which are present in the soil.

Antheridia appear both in ameristic and meristic prothalli in all the three samples. In sample 1 , antheridia of both ameristic\& meristic prothalli are viable \& functional with heavy antherozoidal mass . In sample 2 and 3 antheridia of abnormally branched prothalli are green \&nonviable; become necrotic after a short time ; confirming the presence of heavy metals (Gupta,M. And Devi, S.1992).Antheridia of thalloidameristic male \& meristic bisexuals are few in number than that of the prothalli of sample 1 Antherozoidal mass is scanty both in sample 2 and sample 3 .

ize range of the antheridia of sample $2 \& 3$ shows decreasing trend in size compared to that of sample 1 .

Archaegonia appear in all the samples. Their number shows decreasing trend in number, number archeagonia are more in sample 1 that of the sample $2 \& 3$. Structure of the archaegonia are same in all the specimens, but number of viable archaegonia are less \& number of necrotic archaegonia are more in sample 2 and sample 3 , compare to that of the sample 1 . Table 4.6 shows the size range of antheridia of three sample , their arrival time and arrival time of archaegonia .

Table 4.5 : Sizerange ; arrival time of antheridia, and arrival time of archaegonia of the three samples .

\begin{tabular}{|l|l|l|l|}
\hline Sample & Arrival time of antheridia & Size & Arrival time of archaegonia \\
\hline Sample 1 & $23^{\text {rd }}$ day after germination & $52.30 \mathrm{em}-54.04 \mathrm{em}$ & $56^{\text {th }}$ day after germination \\
\hline Sample 2 & $26^{\text {th }}$ day after germination & $46.06-51.30 \mathrm{em}$ & $60^{\text {th }}$ day after germination \\
\hline Sample 3 & 30 trh day after germination & $42.30-46.15 \mathrm{em}$ & $67^{\text {th }}$ day after germination \\
\hline
\end{tabular}

Fertilization is normal in case of sample 1, where in 93 day old culture $70 \%$ bisexual prothalli and $20 \%$ female prothalli bear sporophytes. In case of sample 2 , sporophyte emerges on 105 days old culture where $40 \%$ bisexual prothalli\& only $5 \%$ female prothalli bear sporophytes . In case of sample 3 , emergence of sporophyte takes place on $120^{\text {th }}$ days old culture where only $25 \%$ of bisexual prothalli and $3 \%$ of female prothalli bear sporophytes.( C. B. Jena (eds.) The percentage of sporophyte emergence \& their arrival time is listed in table 4.7

Table 4.6 : Percentage of sporophyte emergence \& their arrival time in the three samples.

\begin{tabular}{|l|l|l|l|}
\hline Sample & Percentage of sporophyte emergence & Time of sporophyte emergence \\
\hline Sample 1 & Bisexual prothalli & Female prothalli & \\
\hline Sample 2 & $70 \%$ & $20 \%$ & 93 days old culture \\
\hline Sample 3 & $40 \%$ & $5 \%$ & 105 days old culture \\
\hline
\end{tabular}

Reducing trend of sporophyte emergence in sample 2 and sample 3 confirms that these two samples are growing in more polluted area than that of the sample 1 . All the observations show that the sporophytes of sample 2 sample 3 are exposed to the different pollutants present in the sewage $\&$ also in the atmosphere. These pollutants contain many particulate matter $\&$ the salts of heavy metals like $\mathrm{Pb}^{++}, \mathrm{Cd}^{++}$or $\mathrm{Hg}^{++}$which have retarding effect on the developmental pathways of the gametophyte (Ho, B. And Tai, K.U.1985)

\section{Conclusion:-}

According to these observations we can conclude that the sample 1 of Pterisvittata $L$ collected from the garden of khajpura shows the normal developmental pathways ; but the sample 2 and sample 3 of PterisvittataL that are collected near sewage of patliputra industrial area and from crevices of the wall of old house are grown in polluted area and the adverse effect of the pollution will be seen on the developmental pathways of the gametophytes.

\section{Reference:-}

[1]. Das,S.k. Sharma, A, and Talukdar, G. 1982.Effects of Mercury on cellular system in mammals- review, The Nucleus ; 25 (3):193230.

[2]. Dutta K. P. And Sen ,T. 1992. Growth and development of some ferns under different environmental conditions. Indian Fern Journal ; 9:107-112

[3]. Dyer, A. F. 1979. The culture of fern gametophytes for experimental investigation. pp.253-305.In(Ed.A.F.Dyre)The Experimental biology of ferns. Academic press, London

[4]. Francis, P.C. and Petersen ,R.L.1986. Synergis1 .Das,S.k. Sharma, A, and Talukdar, G. 1982.Effects of Mercury on cellular system in mammals- A review, The Nucleus ; 25 (3):193-230.tic and antagonisticresponces of fern spore germination and combination of Copper,Cadmium and Zinc. Bull. Environ. Contam. Toxicol.;30:567-574.

[5]. Gupta, M. and Devi,S.1992.Effect of Cadmium on spore germination and gametophytic development in some ferns. Bull Environ. Contam.Toxicol.; 48:337-343

[6]. Gupta, M. AND Devi,S. And Singh, J. 1992. Effect of low dose exposure to Cadmium during the entire life cycle of Ceratopteristhalictroides, a water fern. Arch. Environ. Contam. Toxicol.;23:184-189 
[7]. Ho, B. And Tai, K.U. 1985, Potential use of road side fern (Pterisvittata) to biomoniterPb and other metal deposition . Bull. Environ. Contam. Toxicol. ;35:430-433.

[8]. Mishra , M. And Sen, T. 1991. Ontogeny of gametophytes and sex expression in some species of Pteris L. In perspectives in pteridology :Present and future, T.

[9]. N.Bharadwaja and C. B. Jena (eds.)Today and Tomorrow's Printers and publishers, New Delhi, pp.75-81.system in higher organism. The Nucleus ;27(1,2):121-139.

[10]. Mishra,M. And Sen, T.1992.Ontogeny and structure of gametophytes in PterislinearisPoir.Indian fern Jour.; 9 :60-65. 